\title{
Santiago: Modernisation, segregation and urban identities in the twenty-first century
}

This paper discusses research carried out in Santiago, Chile, and addresses the origin and construction of urban identities in this segregated city of the twenty-first century. Based on sociological and ethnographic evidence, urban identity-building processes are analysed by observing the occupation, use and appropriation of territory. The hypothesis is that, despite evidence of segregation, modernisation and globalisation, urban people reinvent lifestyles within their territories in order to harmonise their bonds of affection and belonging by using distinguishing markings or "brands" and by adopting typical everyday habits. The modern, segregated and global city is filled with "islands" that convey imagery and desires for a friendlier urban life. This paper analyses areas with community identities, neo-community identities and border identities. It suggests that, just as community identities shelter nostalgia for a lost community (by finding refuge or reinventing ways to make the fringes of the city habitable in the background or on the "other side" of the Mapocho River and very near the historical centre of the city), border identities have also arisen and persisted; these subvert the orderly and hegemonic city, resulting in a diverse, heterogeneous and multicultural lifestyle. The result is a synthesis and an urban lifestyle.

Keywords: segregation, identities, city, ethnographies, Chile 


\section{Introduction}

This paper presents research carried out in Santiago, Chile, and addresses the origin and construction of urban identities in this segregated city of the twenty-first century. The goal of this research was to understand the social processes through which segregation was historically consolidated in the city and the identity-building processes that contributed to reinforcing urban segregation throughout the twentieth century, as well as the tensions created by these situations.

Along with Argentina and Uruguay, Chile is one of the most urbanised countries in Latin America. The population has been predominantly urban since the 1930s, which is relatively early (de Mattos, 1999). Large-scale residential segregation has characterised the traditional Latin American pattern (Subercaseaux, 1940, 1973; de Ramón, 2000). In the case of Chile, Santiago was segregated from early on. Since Benjamín Vicuña Mackenna's term as public administrator (Span. intendente) in 1850 , an effort was made to differentiate between two cities: the city itself, located in the centre and characterised by opulence, Christianity and intellectualism (education), and the city of the outskirts or "barbarism", located around the edges and described as a concentration of poverty, sickness and vice. In Santiago throughout the twentieth century, elite families were generally concentrated in only one area of growth that united the centre of town with the outskirts. At the other extreme of the social ladder, poorer groups tended to become concentrated in broad zones of poverty, particularly in the outermost and worst-equipped outskirts (de Mattos, 1997; Sabatini \& Cáceres, 2001), either in the south or north of the Mapocho River. The history of the city shows that when indigenous families came to live in the city of Santiago they always dwelled in the poverty belts - in the "barbarous" city, as Vicuña Mackenna called it. The main belt was formed along the north bank of the Mapocho. This was a U-shaped area where Santiago met the foothills of the Andes, as the historian Armando José de Ramón pointed out, explaining the stampede of the upper classes eastward, towards the Andes Mountains. Nevertheless, from the end of the nineteenth century through the mid-twentieth century, a quarter of the poor residents of Santiago lived in shacks, densely populated alleyways and ramshackle homes in the fringe neighbourhoods to the south and the north of the city (de Mattos et al., 2006).

The national census of 1952 showed that the population of Santiago had grown to 1,350,409 from just over 900,000 residents in 1940. The space covered by the urban area had also grown at a dizzying rate, and Santiago had become a city of the masses (de Ramón, 2000). The 1950s were characterised by large migratory flows of people caused by the crisis of the economic model based on exporting raw materials and estab- lishing an industrialised economy to substitute for imported goods. This changed the rhythm of Santiago's growth. In 1959 the residents of the poverty belt around the city represented 8\% of Santiago's population (Espinoza, 1988). Higher-income residents began to leave the centre of Santiago to settle in areas east of the city, "leaving their show of status and wealth" as displayed in the imposing architecture along central residential streets such as Dieciocho and Ejército (Merino, 2000).

By 1979, Chile's military government had begun an urban reform program that caused an explosion of urban growth. Their plan to eradicate certain neighbourhoods made living conditions even harder for the poorest residents. This consolidated a pattern of urban segregation and established borders within the city. Santiago became recognised as a segregated city "on a grand scale", characterised by extensive zones of poverty, especially to the south and the northwest of the city and, at the same time, the conglomeration of high-income groups in eastern areas (Sabatini, 1998). In the 1990s, a new process of territorial segregation began on a smaller scale with the construction of modern, fenced-in condominiums in traditionally popular municipalities. In the context of reinforcing its role as a metropolis, the social structure of Santiago is continuing to follow lines of social polarisation and segregation. There is also a spatial or territorial structure that reflects the trend of population loss in the central midtown area and population growth around the edges, as is the case in other large metropolitan areas in developed and emerging nations. Given the evidence provided by ethnographic research, this suggests that the imprint of the city itself and the "barbarous" city persist today as different ways of living in urban spaces. Historically, opposing and contradictory identities are superimposed and coexist in Santiago, defined by their own stories and their everyday practices. The manner of living in the city itself is modern, fast-paced, spatially orderly and involves zoning, control and vigilance. The city itself is built upon an appreciation of place based on the principle of how residents distinguish and identify (Bourdieu, 1987) themselves with their equals and how they display a personality that goes hand-in-hand with a marketplace in which the landscape is built and sold in line with an aesthetic sense of homogeneity and a purity of lifestyle. However, this city also shares a border manner of living, which is a way of living in the "barbarian" city, a style or habitation built up from the chaos and disorder conferred on it by its residents regardless of the state and the marketplace (Jacobs, 1993). It is a lifestyle comprised of a diversity of everyday rhythms and biographies (quick and slow) that subverts spatial orderliness, is built by those that live there and is as diverse as the identities of the builders. These are territories in which relationships of topophilia (Tuan, 2007) are established by multiple brands, or symbols, and sensations of belonging. In this apparent urban disorder, feeling oneself to 
be part of the territory is always a possibility. It is also within this everyday flow of movement and the spontaneous occurrence of "the possible" that the landscape of how people live in the urban space becomes a stage design, a backdrop that is set up and taken down according to the timing and paths of those that live there (de Certau, 1990).

The question of the urban ethos today seems to be this daily struggle between the city itself - hegemonic, controlling and homogenising through segregation and zoning structures and the "barbarous" city, which subverts, and at times reverts, the basic principles of the city itself as a revindication of the multiplicity of urban lifestyles. However, the city of today is not built on conflict alone. The hypothesis is that, despite evidence of segregation, modernisation and globalisation, the urban population reinvents lifestyles within its territories in order to harmonise bonds of affection and belonging by using distinguishing markings or "brands" and adopting typical everyday habits (Márquez, 2009).

This article uses case studies to describe and analyse the social processes that historically contributed to consolidating segregation in Santiago. The hypothesis is that the history of the city is based on two nineteenth-century foundations: the city proper and the "barbarian" city. These categories remain operative in the imaginations and the tales of the city's residents, as principles for distinguishing and identifying themselves spatially and socially.

\section{Modernisation and segregation}

For Santiago residents, the city shows clear signs of modernisation (more homes and buildings, a subway, malls, highways and telecommunications), but there are also elements that make it a territorially and socially segregated city, faithfully

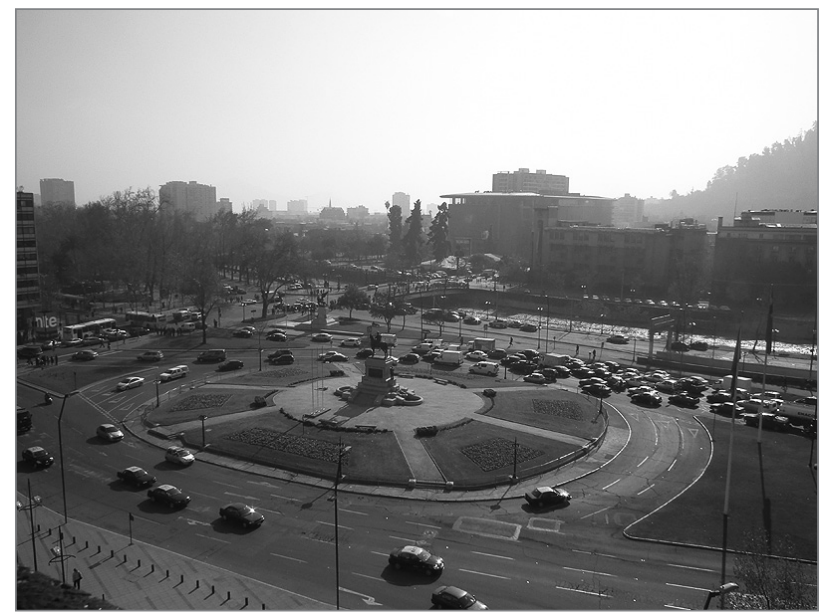

Figure 1: Italy Square (Span. Plaza Italia), the centre of the city of Santiago. Together with the Mapocho River, it marks the boundary between "above and below" (photo: Laura M. González). reflecting the inequality that characterises Chilean society. This contradicts the notion of a metropolis because, as it becomes more modern, it preserves its historical patterns of territorial segregation and increasingly manifests social segmentation and a fear of the Other.

The second half of the twentieth century left a deep mark on both Santiago and the daily lives of its residents. Its accelerated development became embodied in social relations that both overlap and are avoided in today's space. Santiago, like a sort of country in the middle of the nation, hides within itself innumerable borders and interior walls that outline this territory of archipelagos (Santa Cruz, 2002), and makes it difficult for its residents to identify with it as a whole. Economic changes and the concentration of wealth in Santiago have resulted in strongly marked spatial segregation of social levels, with urban areas fragmented in administrative terms, whose delivery of public services are of quite different qualities. Residential segregation can generally be defined as the degree of spatial proximity or territorial concentration of families belonging to the same social group, defined in terms of ethnic background, age groupings, religious preference or socioeconomic status. This is Santiago's main strength: it is built of dimensions and factors that mutually nourish each other. There is a historical and cultural tendency for social groups to concentrate in certain areas of the city, creating areas or neighbourhoods that are socially homogeneous (Márquez \& Pérez, 2008). The practices and identities that the residents construct in these segregated territories confirm their choices. Segregation with historical origins was accentuated by the eradication policy implemented by the military regime of General Augusto Pinochet (1973-1990), which displaced lower-income groups from wealthier neighbourhoods to the belts of poverty around the fringes of the Santiago metropolitan region. Today the statistics of poverty and destitution still show quite a differentiated geographical pattern. The extremes fluctuate between a poverty level of $31 \%$ in the municipality of La Pintana with large social-housing conglomerates on the southern outskirts of the city, and a poverty level of $0.3 \%$ in the municipality of Las Condes to the northeast of the city. The Human Development Index (HDI) for the municipalities of Chile confirms these statistics, including additional indicators for health, education and income levels. The places with the highest HDI are located in the north-eastern areas of Santiago, whereas municipalities with lower income groupings and very low levels of HDI indicators are located towards the northwest and southwest (United Nations Development Programme, 2002).

The uneven distribution of income is illustrated by the distribution of Santiago's population across a map. This shows how residential segregation has a sharply outlined territorial image (Rodríguez \& Winchester, 1999) as well as its labour 
orientation. The clearest example is shown by the data published by the Economic Commission for Latin America at the Latin American and Caribbean Demography Centre (Celade/ Cepal), showing that in higher-income municipalities such as Vitacura and Las Condes more than 60\% of residents only move about within three municipalities of the north-eastern area (Vitacura, Las Condes and Providencia) between their homes and places of employment. On the other hand, in lower-income municipalities only $20 \%$ of the residents work in the same municipality where they live and the rest have to travel to other areas (Rodríguez, 2001). Persistent residential segregation tended to worsen with increased unemployment, delinquency and levels of family violence in certain territories. The tendency of the poorest and most marginal territories to become ghettos not only contributed to the strong stigmatisation of their residents, but also eroded and destroyed the organised elements of urban living, gradually creating a city of fear and caution. The perception of insecurity in the city and in one's own neighbourhood increases in proportion to the decrease in family income. Whereas $71 \%$ of people in upper-income neighbourhoods feel secure there, only 55\% of people in lower-income areas feel that their neighbourhood offers them security. The most telling figure is that both the poor and wealthy alike feel very insecure in the centre of Santiago (71\%), which is by definition a public and diverse area.
In the 1990s, small-scale territorial segregation began to appear as a result of the construction of modern gated condominiums in traditionally popular municipalities. The increase and consolidation of social inequality, the loss of control of a territory by the group that belonged to it, the crisis of the state with regard to guaranteeing the security and protection of all citizens, insecurity, the rise of a model of private citizenry based on "self-regulation" and the consequent privatisation of social life are some factors mentioned when analysing the appearance of these walled citadels within the city (Salcedo \& Torres, 2004). What is certain is that these "beauty marks" of wealth on the face of poverty create new social and spatial borders in the city. Without doubt, the breakdown of public spaces, polarisation and increasing distance between home and the workplace, lack of intermediate spaces and so on make the fundamental issue of the nature of the city more complex and indescribable. Numerous studies warn of the de-territorialisation of elements that create identity, leaving fractured masses that only have vague memories of a collective history (Silva, 1996; Salman \& Kingman, 1999).

This presentation posits that identities have been segregated and fragmented, reinforcing the principles of a local or territorial history that is foreign to the history of the city as a whole. The city is the sum of tiny histories sustained by the

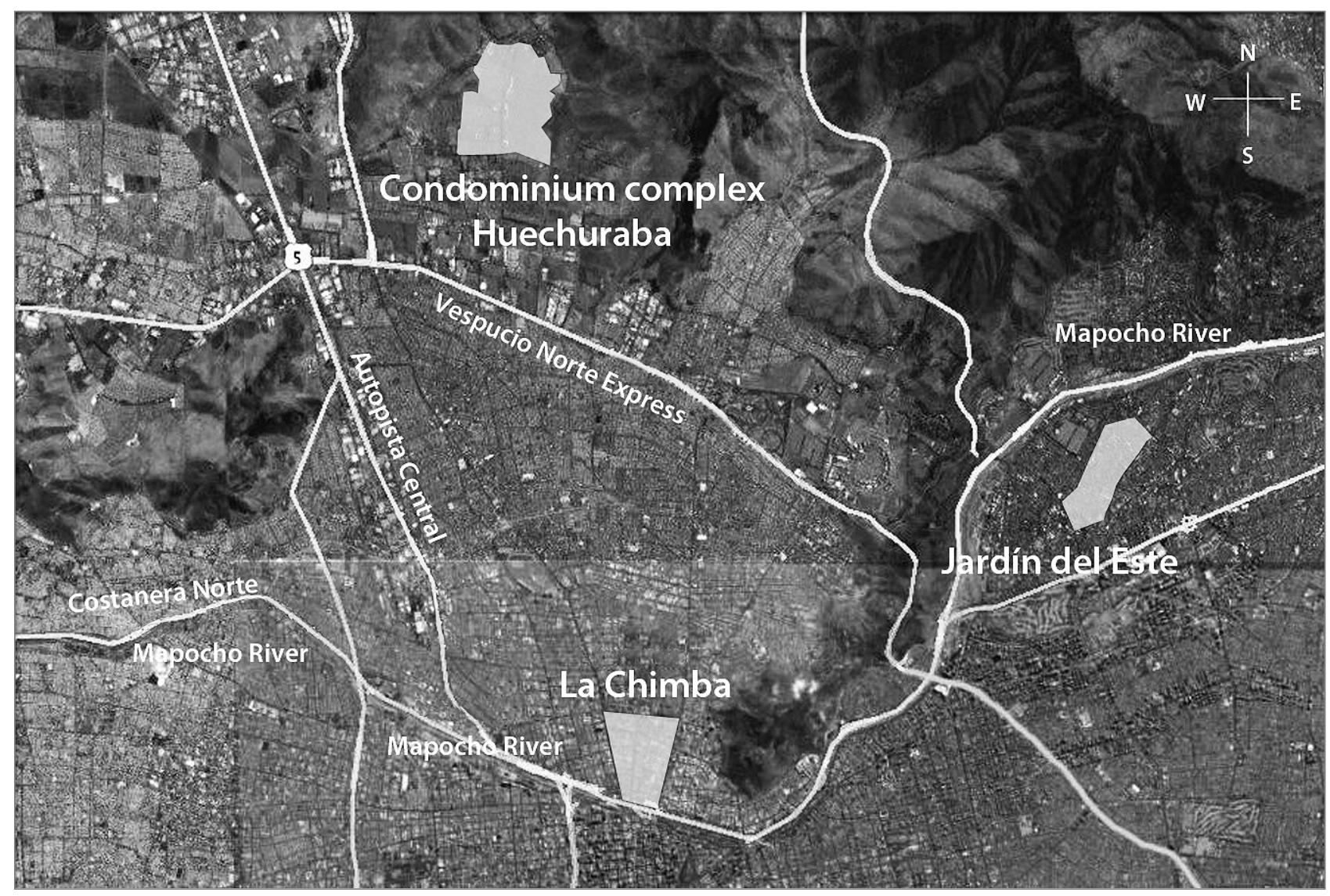

Figure 2: Map of Santiago (source: Internet 1). 
principles of the city itself and of the "barbarous" city, the legacy left by Vicuña Mackenna and the policies of city planning over a century ago.

\section{Urban ethnography}

The methodology used for this article is based on qualitative studies, privileging an ethnographic focus centred on direct observations, in-depth interviews and discussion groups with residents of residential areas. This orients the understanding of the processes that create the lifestyle in the city. Ethnographic descriptions write about cultures and assume direct observation of social behaviour; that is, familiarisation with the groups and individuals being studied. Fieldwork is at the centre of this, involving observation and a determined effort to appreciate "otherness". The process of painting an ethnographic picture of these neighbourhoods was begun in 1998 and continues today. The objective is to create a comprehensive description of the contexts in which the residents live their daily lives. The following dimensions affecting how people to go about their daily business are dealt with: a) social and material characteristics of the people living in these parts of Santiago; b) formative histories and memories; c) local social imagery; d) residents' principles of identification ("us") and distinctiveness ("them"); e) recognition and alliance with the city; f) practices and routes and g) daily interactions that characterise each locality with regard to state administration and the real estate market. This article draws on major conclusions from research carried out in three social or cultural strongholds that coexist in Santiago.

The ethnographic findings presented here were made over a period of 10 years, focusing on the observation of public spaces, particularly streets, plazas, service areas and commercial

Table 1: Ethnographic guidelines of the research

\begin{tabular}{|c|c|}
\hline Guidelines & Means/indicators \\
\hline \multicolumn{2}{|l|}{ 1. History of the neighbourhood } \\
\hline $\begin{array}{l}\text { 1.1 Origins; historical benchmarks; names and nicknames used by } \\
\text { residents for their surroundings; identifying principles: "them" } \\
\text { and "us" over time; distinguishing signs and symbols. }\end{array}$ & • Interviews with community leaders and/or key informants. \\
\hline $\begin{array}{l}\text { 1.2 Today's neighbourhood and the neighbourhood where they lived } \\
\text { before, according to the residents. }\end{array}$ & $\begin{array}{l}\text { - Diagrams of the current neighbourhood and the neighbour- } \\
\text { hood where they previously lived. }\end{array}$ \\
\hline 2. Geographical location of the neighbourhood. & $\begin{array}{l}\text { - Plans of the neighbourhood in Santiago, in the municipality, } \\
\text { in the local neighbourhood geographical unit (large-scale im- } \\
\text { ages). }\end{array}$ \\
\hline \multicolumn{2}{|l|}{$\begin{array}{l}\text { 2.1 Geographical boundaries within Santiago and within the munici- } \\
\text { pality. }\end{array}$} \\
\hline $\begin{array}{l}\text { 2.2 Sizes and number of residential units, types of residence and } \\
\text { their spatial distribution. }\end{array}$ & $\begin{array}{l}\text { - Plan of the neighbourhood and its residential units, photo- } \\
\text { graphs. }\end{array}$ \\
\hline $\begin{array}{l}2.3 \text { Equipment pertaining to condominium groupings (sports fields } \\
\text { or courts, meeting places, plazas etc.). }\end{array}$ & $\begin{array}{l}\text { - Observations and a register of businesses and public spac- } \\
\text { es (plazas, organisations, clubs), signage for organisations and } \\
\text { neighbours. }\end{array}$ \\
\hline $\begin{array}{l}\text { 2.4 Neighbourhood service facilities and others in the surrounding } \\
\text { area (education, health, police). }\end{array}$ & - Support with photographs, posters, fliers. \\
\hline 3. Residents & - Information from municipalities, organisations and schools. \\
\hline \multicolumn{2}{|l|}{ 3.1 How many residents and how many families. } \\
\hline \multicolumn{2}{|l|}{ 3.2 Who they are: gender, age, type of family unit. } \\
\hline \multicolumn{2}{|l|}{$\begin{array}{l}\text { 3.3 Family networks, map of the networks in the neighbourhoods. } \\
\text { Who is the parent of whom? }\end{array}$} \\
\hline \multicolumn{2}{|l|}{$\begin{array}{l}\text { 3.4 Socioeconomic characteristics: the working population, the un- } \\
\text { employed and/or non-working, education levels, trades/profes- } \\
\text { sions, approximate family income levels. }\end{array}$} \\
\hline \multicolumn{2}{|l|}{ 3.5 Residential origins: where do the families come from? } \\
\hline $\begin{array}{l}\text { 3.6 Means of arrival in the new neighbourhood (government hous- } \\
\text { ing subsidy, private savings, loans, etc.); how was the home } \\
\text { purchased? }\end{array}$ & \\
\hline
\end{tabular}

Source: Márquez (2009). 
establishments. Neighbourhood relationships were carefully described from the perspective of Michel de Certau, focusing on residents' everyday practices and routes. After the ethnography study was finished, twenty interviews were conducted in each neighbourhood using a "commented description technique", which involves touring the neighbourhood together with residents in order to identify outstanding places, making a photographic record and analysing census data as elements of geo-referencing. The geo-referencing made it possible to observe the evolution of socioeconomic and demographic indicators by area and thus complement the ethnographic characterisation.

The three neighbourhoods are: a) Barrio Jardín del Este ("Eastern Garden") in the north-eastern municipality of Vitacura; b) the condominium complex of El Carmen de Huechuraba in the north-western municipality of Huechuraba and c) Fariña Street, in the neighbourhood of La Chimba, in the north-western municipality of Recoleta. The case study of these residential "strongholds", or "citadels", is based on the premise that, if a given social manifestation is a construct taken from the society as a whole, then that manifestation as expressed by its "sense of place" (Setha \& Lawrence-Zúñiga, 2003) also draws on the wholeness of society. What occurs in a given place is not independent of the whole that surrounds it or of its neighbouring localities. What happens in a given place, however small that may be, is always the result of the movement of the entire social group (Santos, 1996).

\section{The cultured neighbourhood or the garden fortress}

The history of Jardín del Este, the old Chacra Lo Lillo, goes back to the days of the arrival of the Spaniards and the allotment of land by royal decree. It was on these valuable and favoured lands that the residential neighbourhood of Jardín del Este was created in 1954. Its distance from the centre of town, plus abundant vegetation and water sources, fed the desire for

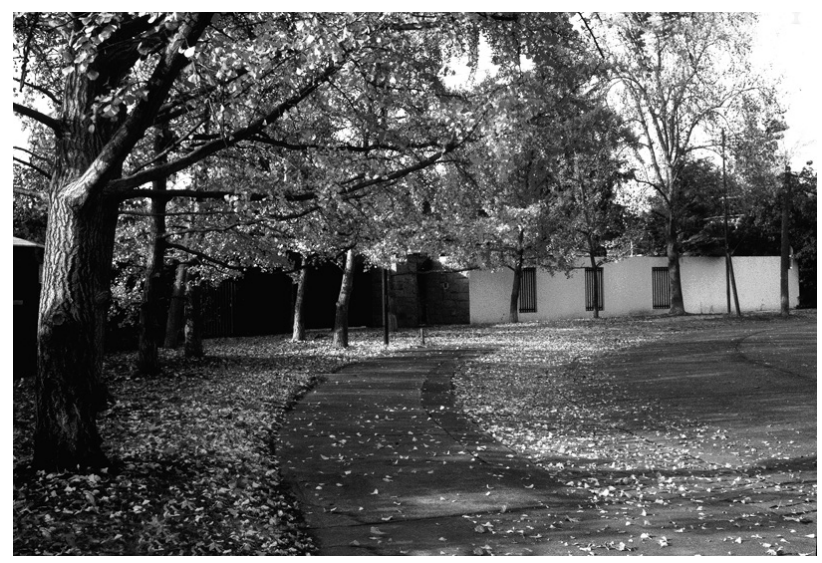

Figure 3: Barrio Jardín del Este (photo: Guillermo Labarca). a better quality of life for its new residents. The building of roads and streets, the subdivision of the land and the installation of utilities echoed the expansion of Santiago with the exodus of the elite toward the northeast of the city. Jardín del Este, as its name suggests, gave its first urbanised areas fanciful names (Palmer Trias, 1987), creating a certain image of the significance of quality of life in an urban context. The word jardin 'garden' is a diminutive of Old French jart or Spanish buerto 'orchard' (Corominas, 1973) and refers to a residential space characterised by a bucolic atmosphere, a place stylised for "country living". Jardín del Este is a local, one-of-a-kind version of the utopian model of the garden city proposed by Ebenezer Howard (1969). It is sui generis because of its homogenous social composition and exclusive brand name, as well as its adherence to the traditional patterns of socioeconomic segregation that characterised historic Santiago. Jardín del Este is definitely an elite suburban neighbourhood on the outskirts of an already consolidated city. The design of Jardín del Este creates a break with the city despite the mix that is a result of combining modernity in architectural style and a tradition in landscaping and layout that gives it character as a "garden city". This design does not leave room for city services, recreational infrastructure or workplaces. The neighbourhood is characterised by being disconnected from the main elements of urban life, more of a "bedroom area" that expresses and consolidates a given lifestyle. Unlike the traditional neighbourhood elsewhere, there are no shops, businesses or offices in Jardín del Este (except for the Alianza Francesa school).

The aesthetic of nostalgia for a rural atmosphere has been taken from the garden city design concept, expressed by the winding roads that border the area and define its internal layout, all made practical by their accessibility to and from highways (Kos, 2008). The layout of the winding streets and the luxurious vegetation around the homes protect them from the noise and movement of cars. Since its beginning, the high quality of architectural design (Duhart, 2006) has made this neighbourhood one of most exclusive areas of upper-class Santiago society. Jardín del Este is distinguished by its carefully maintained beauty and also by the high cultural level of its residents. The private homes in Jardín del Este follow the modern paradigm of single-family occupancy and are set on lots that average 1,000 square meters (about 10,000 square feet). The 200 square-meter houses face inwards towards their own yards and there is an appreciable distance between the houses, the streets and their neighbours. This design element of the neighbourhood accents the orientation towards family life. Daily affairs and surroundings are drawn into the exclusivity of the home. The large number of marriages among the residents' children is an expression of the bonds that are created here despite distances and accepted practices that ensure privacy. Montserrat Palmer Trias (1987) defines residents of 
Jardín del Este as "invisible citizens" whose social life is centred on the polo club. The use of private spaces prevails over public areas, and for residents' lifestyle the home plays the central, supportive role.

The absence of pedestrians is evident to anyone on a weekday. Except for a maid walking a dog, children returning home from school, security guards and gardeners, the streets of Jardín del Este are normally deserted. Although the condition of the sidewalks is inviting, the residents are rarely seen out and about on foot; they generally use cars to obtain services available elsewhere in the municipality. Like many other areas in the eastern part of the city, Jardín del Este is a true reflection of a population that is segregated territorially and professionally: to businesspeople, functionaries of international agencies and professionals whose radius of activity is principally limited to the eastern area of the capital, within the municipalities of Las Condes, Vitacura and Barnechea. In addition to these social homogeneities, there are a number of identity-conferring characteristics that the residents of the area recognise as being the language and the "look" of "us". Among the more obvious structural traits are the winding, peaceful streets, the paving of the sidewalks, the broad pathways, orderly wooded areas, green reminders of the countryside and the "cultured" architecture of the houses that hide behind their front yards without showiness. Whoever enters Jardín del Este will not have any trouble recognising that they are in a carefully designed space where distinguished elements predominate. This cultural wealth, with its styles and tastes, fills out the body of a neighbourhood praxis (de Certeau, 1990), understood as conventions and social norms that tacitly arise to regulate the affairs of the residents and situate them within a universe of mutual recognition.

Like any other residential neighbourhood, Jardín del Este has its own code of conventions regarding the way things are done and the way social relationships are projected and established: no hanging out on the streets, no sweeping the sidewalks, no personal relationships with security guards, no learning the names of the neighbours, no showing off and so on. These are just some of the conventional behavioural traits that describe a particular lifestyle. This lifestyle is also marked by protecting one's privacy, maintaining the "proper distance" and having "good manners". In a territory where the degree of social and economic homogeneity is high, applying these conventional practices is not an obstacle. The lifestyle is precisely that: a culture and a style one is predisposed to lead and project without any need for constant explanation. The courteous greeting in the morning is one of the common gestures that reaffirms the fact that one resides among equals. Within this logic of proper distances, caring for the sanctity of the home and the establishment of sociability behind closed doors assumes a cer- tain relevance. People come together spontaneously and as the occasion demands in order to deal with problems relating to security and the original set of bylaws that could be prejudiced by real estate speculators that want to build high-rise apartment buildings. The ample knowledge that the current residents have regarding municipal and national legislation on city planning, zoning, building codes, architectural details and so on all show the considerable power that cultural patterns (Dubet, 1994) have when applied to protect their practitioners' lifestyle.

\section{Condominiums or walled citadels}

In the northern part of greater Santiago, in the municipality of Huechuraba, is El Carmen de Huechuraba. This is a residential grouping of 25 condominiums where 1,200 young families live in homes measuring between 140 and 172 square metres, on lots that measure 450 square metres and whose value is around USD 210,000. This municipality was traditionally inhabited by lower-income families below the poverty line, and in recent years has been built up with fenced-in residential neighbourhoods for middle-class and upper middle-class buyers. This situation represents a breakdown of large-scale segregation, leading to what has been called small-scale segregation and fitting into the context of the gentrification process (Zukin, 1989) characterising the new processes of spatial segregation.

The young couples that buy homes in these condominiums have an average age of 36 , are professionals, are married and have an average of two children. In terms of their social backgrounds, these families belong to the "aspiring middle class" (Alvarez-Rivadulla, 2007; Atkinson, 2006; Low, 2001). That is, they are young families from middle-class municipalities but are on their way up the economic ladder and have buying patterns that are increasingly like those of the upper classes. ${ }^{[1]}$ Condominiums, private or "country" villas and fenced-in citadels grow and consolidate within the city as a lifestyle among the

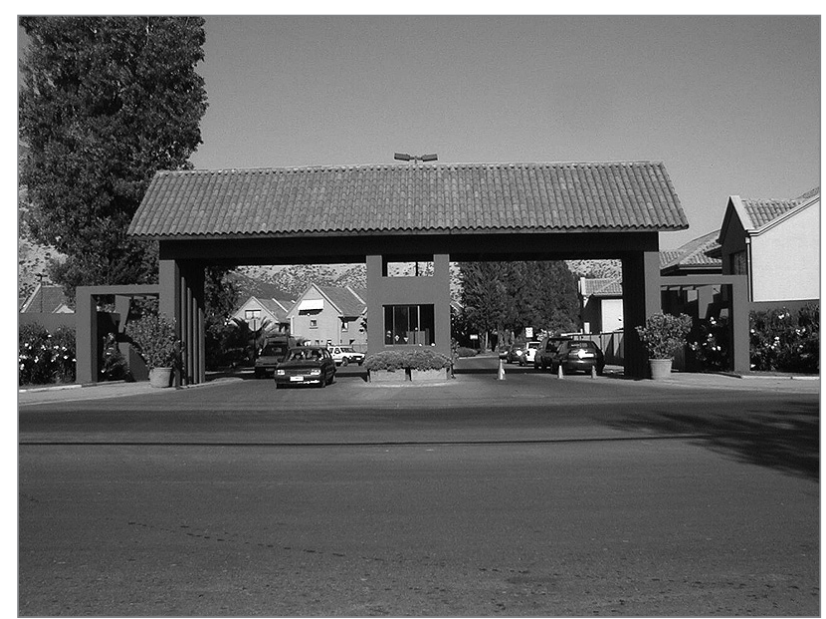

Figure 4: The condominium complex of El Carmen de Huechuraba (photo: Francisca Pérez, Gladys Retamal, Daniela Serra). 
most comfortable in the metropolis. The value given to security behind closed doors and a model of "protected autonomy" (Svampa, 2001) extends beyond these condominiums and out into all other aspects of life: sports, schools, churches and even services and businesses. With their fences and sophisticated private security devices, these high-level condominiums are able to provide longed-for safety. Enclosed within their condominiums, neighbours establish and defend themselves with electric fences and guards, and above all their tales tell of their nostalgia for a rural world that they constantly evoke. The protection and care they give to the yards and natural areas appeals to this nostalgia and implies a return to a community that once existed, a poetic expression of space that colours the past with bucolic dreams and images (Bachelard, 1965). The old farm where the condominiums now stand contributes to this poetry of sharp reminiscence about country living. Relics such as a silo, a cross and a stable for horses are preserved and shown to visitors. Chilean-style houses with their clay roof tiles, juxtaposed with window boxes and "American" yards, fill out this urban scene with rural reminiscence. To paraphrase Néstor García Canclini (1995), to have an identity in Huechuraba is, above all, to have a neighbourhood (not necessarily a country and a city). A space where everything shared by the residents becomes identical and interchangeable, the neighbourhood is therefore the territory where parties are held and daily rituals are dramatised. Those that do not share this territory, or live in it, thus lack the same objects, symbols, rituals and habits, and are seen as the Other; they are different. The Other is tolerated but not frequented even under the most fortuitous everyday circumstances. The relationship with the Other, the poorest, or those that live somewhere beyond the walls of the condominium, is established sporadically, albeit on the basis of a relationship with a service provider (the maids, gardeners and tradesmen) or on the basis of charity, a charity that is brokered by the school in this case, and wholly dependent on conditions of urgency.

Nostalgia, the obstinate search for a life "as it was when we were small", for a neighbourhood, for a certain sociability among peers, for the "pleasure of being together", and for the possibility for sharing are all present in the stories told by and in the everyday practices of these residents. The "tribal character" that these families have managed to give to their lives - a character that is certainly facilitated by the architectural and urban design of the condominiums - fits the aspirations of each of them. Although it does not correspond to the postmodern "tribe" that Michel Maffesoli (2000) speaks about, the "bubble" that these residents mention is something similar. It is the small and protected community that seeks to "give our children the infancy that we had". Confronted by the evidence and the brutality of urban individualism, there appears to be only one solution: reclusion within the narrow, protected, but nevertheless vital, borders of daily life among equals.

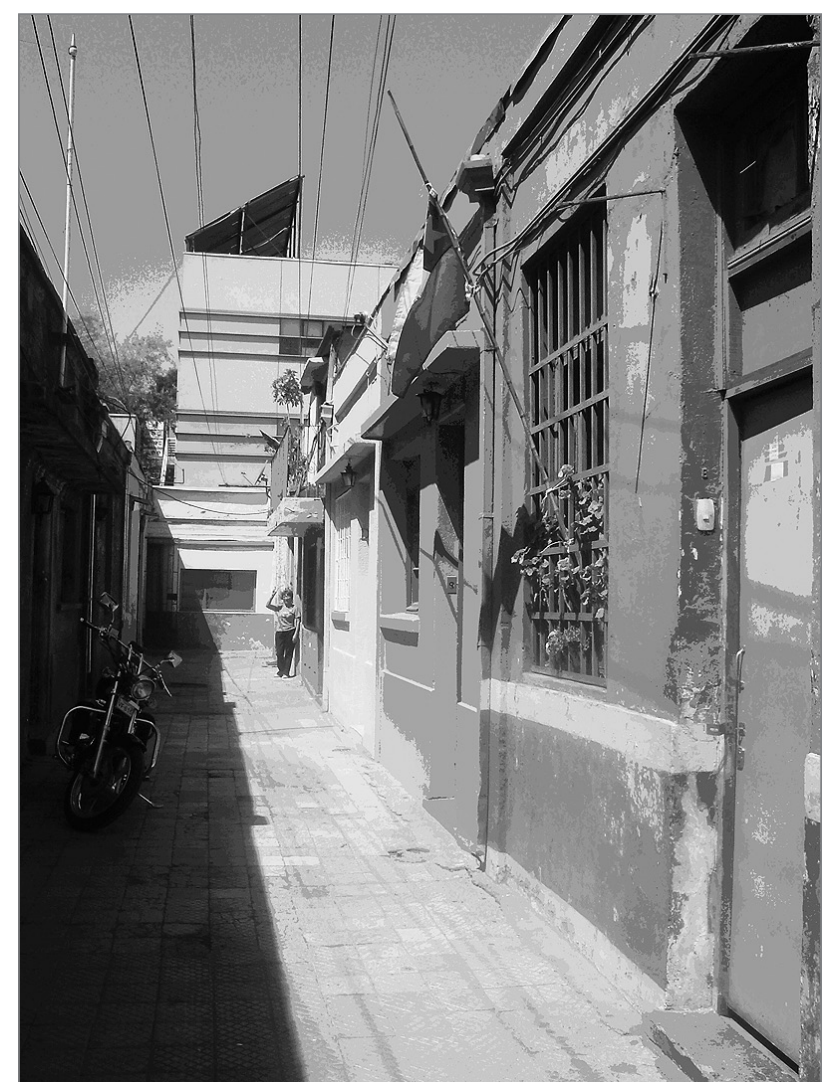

Figure 5: Fariña Street in the La Chimba neighbourhood (photo: Francisca Márquez).

The walled spaces - with their guards, alarms and electric fences that separate and protect their residents from the residents of La Pincoya - have their correlation in terms of identity. Within the community of equals, references to an imagined community are scant, in terms of what Benedict Anderson (2000) mentions as a nation state. The principles of integration begin and end at the edges of the condominium and the community of equals, with its highly privatised citizenry where the development company and its post-sales office replace the state.

\section{La Chimba, or the border citadel}

La Chimba, north of the Mapocho River, has historically been Santiago's "other side". The narrow strip of the river marks the boundary between the city itself and the barbarian city. Since the sixteenth century, during the colonial period, La Chimba has been the place for what the centre of the city has denied: the cemeteries, the hospitals, the farmers' market, the Indians and impoverished immigrants seeking better fortune. For four and a half centuries, La Chimba has been the border, the backroom, as well as a sanctuary and a place of characteristic diversity. This not only survives in the symbolic segregation of the dead on the other side of the Mapocho River - the territory of the Other - but is perpetuated in the districts populated with a mixture of people that sustains the vitality of this territory (Franz, 2002). La Chimba defies central planning and 
has become emblematic of a certain degree of self-sufficiency. If the centre of Santiago is the face of legality and civility, then La Chimba is the backside, the other side of the coin, the opposite - a parallel citadel on the other side of the river. La Chimba today is comprised of four municipalities; There are three strip-like spatial elements of this territory: a) Bellavista, with its nightlife, bars and restaurants; b) Patronato, with its immigrants and shops; and c) La Vega, with its warehouses from Recoleta to Vivaceta. Loaded with meaning, in Quechua, chimba means 'the land, neighbourhood, or locality on the other side of the river' (Rosales, 1948). The neighbourhood was born when Pedro de Valdivia, the founder of the city and a resident of La Chimba, moved his troops across to the southern bank of the Mapocho River and finally created the city of Santiago de la Nueva Extremadura in those territories. From the moment when Santiago was founded between the branches of the Mapocho, La Chimba received all the Indians that the conquistador did not want to have settled within his city. As a result, the territory of La Chimba constituted an annex: an area beyond the walls of the city where from the outset the servants (Span. yanaconas) and other ethnic groups at the service of the conquistadores settled.

Since the seventeenth to eighteenth centuries, the population of La Chimba has been one of the prime examples within Santiago of multiculturalism together with poverty, and where the lifestyle goes hand in hand with the income-generating process. Indians, blacks, mulattos, mestizos and poor Spaniards worked as tradesmen and in simple manufacturing, and also offered their services to the residents of Santiago. Intense commercial, social and recreational activities created a territory that set the pattern for development of the entire city. The border drawn by the Mapocho River served defensive purposes and provided sanctuary in times of social unrest or repression from the centre of the city against its residents and economic activities (Salazar \& Pinto, 2002). Geographically, the Mapocho River creates the border. It is the dividing line that defines an inside and an outside, a visual limit that one arrives at but also leaves from. It is the edge of a border territory, understood as a place that distinguishes "us" from "them"; a vague and indeterminate place that speaks of a state of permanent change. Its residents are those that crossed that border, the odd ones, the bothersome ones, the undesirable, the mulattos, the Indians, the dead, the crazy, the foreigners; those that already crossed the border or walk the precarious limit of what is normal (Anzaldúa, 1999). In this sense, La Chimba also grew as a symbolic receptacle of what is bad and provides a place where all those that do not have a place in the middle of town can live together. As a border territory, La Chimba sets limits and excludes as well as integrates, distinguishes and identifies. Far from being a transitional zone, La Chimba arises as a physical and symbolic territory in which the reference points are formatted to define the city of the Others, the "barbarian" city, without which the urban condition as an experience of diversity could not exist (Mongin, 2006).

Space is feminine in La Chimba, receptive, a uterus, a possibility that is always open and receptive. This side of its character explains its profound malleability and capacity for transformation: an alleyway can be residential in the morning, a nursery where children are cared for, a warehouse in the afternoon, an "informal" bar at night, a workplace for prostitutes, a restaurant and once again residential. The malleability of spaces to receive, provide refuge and "hide" or "protect" their residents is a trait that the city itself, through its zoning policies, is unable to accept. La Chimba is not a marginal, low-cost housing project, nor a squatter community nor a ghetto. In La Chimba there is no room for modern zoning practices and urban planning. In La Chimba, one is face to face with a city - another city - where the principles of urban design so loved by Jane Jacob (1993) assume all of their force and meaning. As pointed out earlier, the key to understanding this part of the city would appear to be precisely that fluidity of neighbourhood relationships that are not based on residence or the fact that one lives there. There is a neighbourhood economic base - strongly accented by La Vega and the commercial districts - where everyone produces for everyone, but in such a manner that only those that live there can know it and decode it.

Everything is in motion, everyone has his place and xenophobia - so present in the city proper - loses all possibility of becoming established. The Other, the one that is different, always contains the potential for becoming, and stigma - understood as the brand, or mark, that fixes one in place - loses all reason for being. La Chimba is and has been a place characterised by a plasticity that certainly has little to do with the structured and segregating logic of a city like Santiago. In Santiago, as in other Latin American cities, the fault line in the urban topography is a good illustration of the persistence and consolidation of a lifestyle among groups that are socially homogenous and share an identity. The city proper and the "barbarian city" live together in a play of mirrors that seems to resist an urban model based on heterogeneity, exchanges among different people and the idea of public space and values such as a politically aware citizenry and social integration.

Sociability among equals assures urban segregation and the resulting residential homogeneity of Santiago, opening the way for an image and a manner of social behaviour that strengthens and protects "us" against and from the danger of "them". Insofar as within the city itself, or the city proper, some people project and consolidate the urban design of affinities, this model lifestyle among equals guarantees "sociability among ourselves", whereas in the "barbarous" city evidence of inequal- 
ity permeates their projects and even their most commonplace daily encounters.

\section{Conclusion}

To perceive Santiago from the point of view of the "other side" makes it possible to point out that the city is made up of these superimposed and multiple identities, this crossing of worlds in conflict. It can be pointed out that the Mapocho River acts like an abyss between two continents, two cities, that do not look at each other despite their coexistence and being superimposed upon one another - in other cities it would be the railroad line, or a dump, an imaginary border. However, the river has bridges across it, and these bridges are what allow the border to be continually violated, to be transgressed, although this fact does not deny that it is firmly in place. Whoever crosses this border must fear for his life, a life that could become corrupted as are the imaginary case studies or plots of popular novels throughout the twentieth century. However, it is the very existence of these bridges between the city proper and the "barbarian" city that give life to the urban condition (Mongin, 2006), as was celebrated by the early musings of sociologists at the end of the nineteenth century. From both sides of the border, cultural landscapes (Zukin, 1989) are created to concretise the memories of cities, of what is subordinate and what is dominant. Facing the city proper and order, the "barbarian" city challenges central planning and declares itself to represent a certain degree of self-sufficiency. If the city itself is the face of legality and civility, the "barbarous city" is the backside, the "tail" of the coin and the opposite number, a parallel city set on the border, on the edge of legality, on the fringe of the dominant rules and codes of conduct.

The "barbarian city", by definition a border territory, outlines and also excludes and integrates, distinguishes and identifies. More than a zone of transition, the "barbarian city" arises as a physical and symbolic territory in which there are reference points for various identities that will give shape and substance to "the city of the Others". It is this condition of being a border that speaks of the multiple cities that have been dislodged and torn out of the city proper: that of the conquistador Pedro de Valdivia in the sixteenth century, that of Vicuña Mackenna in the nineteenth century, and that of the real estate market of the twenty-first century. The barbarous city intensifies the homogenising and dominating projects of urban planning. La Chimba and the squatters' camps of the cities are reminders that, more than the places one identifies with, what is found there are midway places and crossroads that are transfixed by multiple sensations of cultural belonging and places with identity. Transverse and border identities thus subvert the paradigm of fixed, flattened identities of the city proper. The cultural identities of the "barbarian" city are reminders that every iden- tity is a construct, never essential but rather a posturing with no total guarantee (Hall, 1996). Identities are a field of conflict and they depend on a sincere recognition of otherness to grant them recognition and legitimacy.

The meanings that feed those identities do not originate solely in flowery statements; an important source of these meanings is found in concrete practices realised within concrete contexts. This condition of identity is what is called territoriality; and what other authors attribute to the ability to love a place (Lefebvre, 1976). Territoriality is a trait shared by social beings and is therefore a basic component of identity, a component that certainly weighs differently according to the diverse historical influences experienced, but also according to the subject's position within the social structure. In this sense, a hypothesis is posed that argues that - behind the apparent disorder of the "barbarous" city, the most obvious manifestation of which is the systematic transgression of the norms and regulations governing spatial management and architecture - there is a logic and body of social concepts that regulate the relationship between individuals and territory, and that organise their behaviour in the urban sphere. The apparently unregulated processes are set down, through their practice, in a series of unwritten norms that represent a desire for belonging and draw upon both an orally expressed memory and everyday behaviour (Qadeer, 2004). These practices involved in living somewhere partially obey the wish to appropriate and make use of urban spaces, and they are informal tactics that, nevertheless, respond to a social logic that is not represented in the hegemonic habitation of the city proper.

Urban spaces are not variables that are foreign to these lifestyles, and the transgression of existing norms demands the provision of residual spaces where those lifestyles can be made manifest. The metropolitan space accepts within itself a diversity of habitats that tell of various habits and ideas of habitation. Of course, these differences go hand in hand with urban or residential segregation. It is the "effect of place" (Bourdieu, 1993). Therefore, urban research represents a double challenge: first, to understand the logic, norms and practical reasons involved in social experience and everyday productivity in the metropolis and, second, to establish the relationship between the means of production within the city proper and within the "barbarian" counterpart so that they facilitate each others' reproduction, but, above all, to comprehend the dominion of one lifestyle over the other. This means that it is not possible to understand what is happening - or what is not happening - in the city proper (and its citadels) without referring to what is happening in the "barbarian city" (and its citadels). The means of production of the one are implemented together with the Other, in complicity with the Other and despite the Other. The citadels certainly build lifestyles that 
correspond to the possibilities, desires and projected imaginings of their residents, but also in line with the possibilities, interests and projections of the metropolis as a whole. The social construct of the citadels is by definition otherness and totality. The metropolis is a game of mirrors that by definition is never resolved, and this is what grants it its truly urban and modern character (Mihelič, 2008).

In Santiago, the seal of the city proper would appear to be to point out and dominate the urban lifestyle. It is the means of production of the dominant space that gives order to the city and also to the projected imagery of its residents (Wellman, 1979). The character of the "barbarous" city as being a uterus, a community and a refuge is an answer and also an expression of resistance to the practices of control and organisation exercised by the city proper. The breach between both cities is and historically has been a structural facet of the urban order, the consequences of which are seen today in the urban practices and expressions of segregation. The persistence of a "barbarian" city speaks of resistance and a complaint against the historical presence of a city itself that organises not only the territory but the other ways of projecting and living in the large, neoliberal city that Santiago has become.

Francisca Márquez

Alberto Hurtado University, Faculty of Social Sciences, Santiago,

Chile

E-mail:fmarquez@uahurtado.cl

\section{Notes}

[1] Only 6\% come from provinces outside the greater Santiago metropolitan area. Fifty-eight percent tried to purchase homes in Las Condes, but were unable to pay the high prices of houses there. For them, Huechuraba was their fourth choice, after Vitacura and La Reina.

\section{Acknowledgements}

The article is validated by the findings of research conducted by the author: "The Others City: Immigrants in Frontier Territories: La Chimba in the Twentieth Century", Fondecyt no 1095083, National Commission for Scientific and Technological Research - CONICYT, Chile. Special thanks to Richard Dodge, who translated this paper into English, richard.dodge@gmail.com.

\section{References}

Alvarez-Rivadulla, M. J. (2007) Golden ghettos: gated communities and class residential segregation in Montevideo, Uruguay. Environment and Planning A, 39(1), pp. 47-63. DOI: 10.1068/a38469

Anderson, B. (2000) Comunidades imaginadas. Buenos Aires, Fondo de Cultura Economica de Argentina.
Anzaldúa, G. (1999) Borderlands - la frontera: The new mestiza. San Francisco, Aunt Lute Books.

Atkinson, R. (2006) Padding the bunker: Strategies of middle-class disaffiliation and colonisation in the city. Urban Studies, 43(4), pp. 819-832. DOI: 10.1080/00420980600597806

Bachelard, G. (1965) La poética del espacio. Buenos Aires, Fondo de Cultura Economica de Argentina.

Bourdieu, P. (1979) La distinction. Paris, Minuit.

Bourdieu, P. (1993) La misère du monde. Paris, Seuil.

Corominas, J. (1973) Breve diccionario etimológico de la lengua castellana. Madrid, Gredos.

De Certau, M. (1990) L'Invention du quotidien tome 1, arts de faire. Paris, Gillamard.

De Mattos, C. (1997) Dinámica económica globalizada y transformación metropolitana: hacia un planeta de archipiélagos urbanos. Paper presented at the 6th Encuentro de Geógrafos de América Latina of the Institute of Geography, Faculty of Arts and Letters, University of Buenos Aires, 17-21 March, Buenos Aires, Argentina. Typescript.

De Mattos, C. (1999) Santiago de Chile, globalización y expansión metropolitana: Lo que existía sigue existiendo, Eure, 25(76), pp. 29-56.

De Mattos, C., Figueroa, O., Bannen P. \& Campos D. (eds.) (2006) Santiago en EURE. Huellas de una metamorfosis metropolitana 1970-2000. Santiago, IEU+T, PUC.

De Ramón, A. (2000) Santiago de Chile. Santiago, Ed. Sudamericana.

Dubet, F. (1994) L'experience social. Paris, L'Harmattan.

Duhart, E. (2006) El arquitecto Emilio Duhart (1918-2006) [interviewed by Fernando Pérez Oyarzún \& Pilar Urrejola Dittborn]. ARQ, 62, Mar. 2006, p. 78.

Espinoza, V. (1988) Para una historia de los pobres de la ciudad. Santiago, SUR.

Franz, C. (2002) La muralla enterrada. Santiago, Planeta.

García Canclini, N. (1995) Consumidores y ciudadanos. Conflictos multiculturales de la globalización. Mexico City, Grijalbo.

Hall, P. (1996) The creative city in the third millennium. Paper presented at the International Conference on Urban Development and the Information Society of the University of Art and Design Helsinki UIAH, 15-16 August, Helsinki, Finland. Typescript.

Howard, E. (1969) Les cités jardins de demain. Paris, Ed. Dunod.

Internet 1: www.google-earth.softonic.com (accessed 15 Jun. 2011).

Jacobs, J. (1993) The death and life of great American cities. New York, Modern Library.

Kos, D. (2008) Narava $v$ mestu ali mesto $v$ naravi? [Nature in the city or the city in nature?] Urbani izziv, 19(2), pp. 5-9 [129-132]. DOI: 10.5379/ urbani-izziv-en-2008-19-02-001

Lefebvre, H. (1976) Espacio y política: El derecho a la ciudad, II. Barcelona, Península.

Low, S. (2001) The edge and the center: Gated communities and the discourse of urban fear. American Anthropologist, 103(1), pp. 45-58. DOI: 10.1525/aa.2001.103.1.45

Maffesoli, M. (2000) Le temps des tribus. Paris, La table ronde.

Márquez, F. (2009) La ciudad de los otros inmigrantes en territorios de frontera: La Chimba en el siglo XX. Research report [Fondecyt no. 1095083]. Santiago, National Commission for Scientific and Technological Research - CONICYT. 
Márquez, F. \& Pérez F. (2008) Spatial frontiers and neo-communitarian identities in the city: The case of Santiago de Chile. Urban Studies Revue, 45(7), pp. 1461-1483. DOI: 10.1177/0042098008090684

Merino, R. (2000) Santiago de memoria. Santiago, Planeta.

Mihelič, B. (2008) Podoba mesta 1900:2000 [The image of the city 1900:2000]. Urbani izziv, 19(1), p. 3 [4].

Mongin, O. (2006) La condición urbana: La ciudad a la hora de la mundialización. Buenos Aires, Paidós.

Palmer Trias, M. (1987) La ciudad jardín como modelo de crecimiento urbano. Santiago 1935-1960. Santiago, Universidad Católica de Chile.

Qadeer, M. (2004) Segregacao étnica em uma cidade multicultural. Espaco \& Debates. De Estudos Regionais e Urbanos, 24(45), pp. 34-46.

Rodríguez, A. (2001) La vivienda privada de ciudad. Santiago, SUR.

Rodríguez, A. \& Winchester, L. (eds.) (1999) Ciudades y gobernabilidad en América Latina. Santiago, SUR.

Rosales, J. A. (1948) La Chimba antigua. Historia de la Cañadilla. Santiago, Difusión.

Sabatini, F. (1998) Transformación urbana y dialéctica entre integración y exclusión social. Reflexiones sobre las ciudades latinoamericanas y notas sobre Santiago de Chile. Santiago, Urban Studies Institute, Catholic Pontifical University of Chile.

Sabatini, F. \& Cáceres, G. (2001) Segregación residencial en las principales ciudades chilenas: Tendencias de las tres últimas décadas y posibles cursos de acción. Revista Eure, 27(82), pp. 21-42.

Salazar, G. \& Pinto, J. (2002) Historia contemporánea de Chile. Santiago, LOM.

Salcedo, R. \& Torres, A. (2004) Gated communities in Santiago: Wall or frontier? International Journal of Urban and Regional Research, 28(1), pp. 27-44. DOI: 10.1111/j.0309-1317.2004.00501.x

Salman, T. \& Kingman E. (eds.) (1999) Antigua modernidad y memoria del presente: Culturas urbanas e identidad. Quito, Flacso.

Santa Cruz, G. (2002) Las ciudades literarias. In: Halpert, M. (ed.) Ciudad y Arquitectura: Otras miradas, otras preguntas, pp. 24-29. Santiago, Ed. U. Central.

Santos, M. (1996) De la totalidad al lugar. Barcelona, Oikos-Tau.

Setha M. L. \& Lawrence-Zúñiga, D. (eds.) (2003) The anthropology of space and place: Locating culture. Malden, Wiley-Blackwell.

Silva, A. (1996) Rito urbano e inscripciones imaginarias en América Latina. Persona y Sociedad, 10(1), pp. 106-115.

Subercaseaux, B. $(1940,1973)$ Chile o una loca geografía. Santiago, Universitaria.

Svampa, M. (2001) Los que ganaron. La vida en los countries y barrios privados. Buenos Aires, Biblos.

Tuan, Y. (2007) Topofilia: un estudio de las percepciones, actitudes y valores sobre el entorno. Barcelona, Melusina.

United Nations Development Programme (2002) Informe desarrollo humano en Chile: Nosotros los chilenos un desafío cultural. Santiago, Mayo.

Wellman, B. (1979) The community question: The intimate networks of east Yorkers. American Journal of Sociology, 84(5), pp. 1201-1231. DOI: 10.1086/226906

Zukin, S. (1989) Loft living. Culture and capital in urban change. New Brunswick, NJ, Rutgers University Press. 